\title{
Estimation of Genetic Variability, Heritability and Genetic Advance in Cucumber (Cucumis sativus L.) for Yield and Its Components under Protected Structure
}

\author{
T. R. Sahoo ${ }^{1^{*}}$ and D. K. Singh ${ }^{2}$ \\ ${ }^{1}$ KVK, ICAR-National Rice Research Institute, Cuttack, Odisha-753006, India \\ ${ }^{2}$ GB Pant University of Agriculture and Technology, Pantnagar, Uttarakhand, India \\ *Corresponding author
}

\begin{abstract}
A B S T R A C T
The present investigation was under taken with the objectives to estimate genetic variability, heritability and genetic advance for yield and yield contributing components of cucumber. The experimental materials for this investigation were fourteen genotypes of cucumber consisting of parthenocarpic, gynoecious and monecious germplasms crossed in line $\times$ tester mating design produced thirty three hybrids $\left(\mathrm{F}_{1}\right)$. Thirty three $\mathrm{F}_{1}$ crosses along with their parents were evaluated in two environments viz. Environment 1 (March-June), Environment 2 (AugustDecember) inside polyhouse for evaluation of their quantitative characters. The genotypes exhibited significant differences for all the traits under study in both environments. The genotypic coefficients of variation and phenotypic coefficients of variation were moderate to high for most of the characters. A wide range of variability along with high estimates of PCV and GCV were observed for node number to first male flower, node number to first female flower, sex ratio: $(\mathrm{M} / \mathrm{F})$, days to first male flower, fruit yield/ plant $(\mathrm{kg})$, and fruit yield $(\mathrm{q} / \mathrm{ha})$ in both the environments.indicating high variability available in the germplasm for these characters for further improvement. High heritability coupled with high genetic advance as percent of mean was observed for fruit length $(\mathrm{cm})$, fruit weight $(\mathrm{g})$, number of fruits/plant, plant height $(\mathrm{m})$, yield per plant $(\mathrm{kg})$, yield per hectare $(\mathrm{q} / \mathrm{ha})$, days to first male flower, node to first male flower, node to first female flower and sex ratio $(\mathrm{M} / \mathrm{F})$. These characters had additive gene effect and therefore, these are more reliable for effective selection. Yield of parthenocarpic and gynoecious cucumber lines could be improved upon by selecting superior characters for further improvement in cucumber breeding.
\end{abstract}

\section{Keywords}

Genetic variability, Heritability,

Genetic advance, Additive gene

Article Info

Accepted:

22 March 2020

Available Online:

10 April 2020

\section{Introduction}

Cucumber (Cucumis sativus $\mathrm{L}$., $2 \mathrm{n}=2 \mathrm{x}=14$ ) is one of the most important member of the family cucurbitaceae including several crops of economic importance. It is thought to be one of the oldest vegetable crops, being grown for at least five thousand years. It is the fourth most important vegetable crop after tomato, cabbage and onion in Asia. The fruits are used for preparation of cosmetic items like soap and cream and in many other ways (Dhiman and Parkash, 2005). The crop is of Asian origin and the progenitor may be closely related to its wild relative Cucumis sativus var. hardwickii, first found in the 
Himalayan mountains (foothills of Nepal) and used by native peoples of Northern India as a laxative (Deakin et al., 1971). India being the primary centre of origin, it has accumulated a wide range of variability providing good extent for improvement in yield and other characters of cucumber through selection.

Owing to the high cross pollination nature in cucumber, it is very difficult to maintain the purity in germplasm. It shows a wide range of variability in existing germplasm and also there is no uniformity in important traits such as fruit size, shape, colour, quality and yield. The parthenocarpic and gynoecious genotypes bear all female flowers in every node producing seedless fruits depending on $p c$ genes in background (Pike and Peterson, 1969). So, variability is found among parthenocarpic and gynoecious genotypes. In general, variability is the basic material for any crop improvement programme. Therefore, knowledge about the existence of genetic variability is the useful adjunct to carry out effective selection for improving yield. Correlation studies helps for deciding which trait contribute towards yield positively or negatively.

Heritability indicates the extent to which improvement is possible through selection and relative degree to which a character is transmitted from parent to offspring. Most of the quantitative characters, which are of economic value, are highly influenced by environment. Therefore, some of the highly heritable characters associated with yield, which are influenced to a lesser degree by environment, serve as an indicator of yield in selection programme (Staub et al., 2006). Additionally, nature of gene action is also important where progress from selection depends primarily on the additive gene action (Afroz et al., 2015, Pati et al., 2015 and Pradhan et al., 2016). Heritability and genetic advance serve as useful tools for the breeders in determining the direction and magnitude of selection. Estimates of heritability have to be considered with conjunction with genetic advance as alone it does not provide idea about expected gain in next generation (Shukla et al., 2006). Relationship between yield and yield associated traits are prime important for direct and indirect selection of traits which contribute to yield. Therefore, this study was carried out to estimate genetic variability, heritability, correlation and genetic advance as percent of mean of genotypes in relation to yield and yield associated traits and its selection in cucumber. The estimate of these parameters in controlled condition like protected structures is useful in formulating suitable selection strategy for higher yield in cucumber. Certain genotypes need to be selected depending upon their stable phenotypic performance in both the environments under a protected structure The present investigation is taken to evaluate available cucumber genotypes such as parthenocarpic, gynoecious and monoecious and their hybrids $\left(\mathrm{F}_{1}\right)$ for assessing genetic variability, heritability, correlation and genetic advance present in various growth and yield related traits.

\section{Materials and Methods}

The present study was conducted at Vegetable Research Centre, G.B. Pant University of Agriculture and Technology, Pantnagar (U.S. Nagar) from August 2015 to December 2016 under two environmental conditions inside polyhouse, viz. E1: Environment 1 (MarchJune) and E2: Environment 2 (AugustDecember).Fourteen genotypes of cucumber Fourteen genotypes of cucumber genotypes consisting of eight parthenocarpic cucumber lines viz., PCUCP-1, PCUCP-2 (Pant Parthenocarpic Cucumber-2), PCUCP-3(Pant Parthenocarpic Cucumber-3), PCUCP-4, PCUCP-5, PCUCP-6, PCUCP-7, PCUCP-8 and three gynoecious cucumber lines viz., 
PGYC-1, PGYC-2, PGYC-3 and three monoecious cucumber lines viz., PCUC-8, PCUC-25, and Pant Khira-1 were crossed in line $\times$ tester mating design to obtain $33 \mathrm{~F}_{1}$, hybrid combinations. All crosses were made inside polyhouse and seeds from mature fruits were collected for evaluation of $33 \mathrm{~F}_{1}$ hybrid combinations in next season. Thirty three $F_{1}$ crosses along with their parents were evaluated during March, 2016 to December, 2016 inside polyhouse in two environments viz., E1: Environment 1 (March-June) and E2: Environment 2 (August-December) for evaluation of their quantitative characters in a randomized block design (RBD) with three replications. All cultural operations like fertigation with NPK (19:19:19), pruning, staking and plant protection measures were carried out and data for all fifteen quantitative characters were recorded.

The experiment was laid out in a RBD with three replications each under polyhouse with an area of $500 \mathrm{~m}^{2}$. Each genotype within a replication consisted of nine plants. The spacing between rows was kept $0.6 \mathrm{~m}$ and within plants $0.45 \mathrm{~m}$. Initially, three seeds were sown in a pit and later one plant per hill was maintained after thinning. Fifteen quantitative traits were scored on each genotype in this experiment. Five plants were randomly selected from each genotype in each replication for recording of observations for all the plant traits viz., Days to first male flower, Node number to first male flower, Days to first female flower, Node number to first female flower, Sex ratio (M/F) Days to first harvest, Days to last harvest, Internodal length $(\mathrm{cm})$, Plant height $(\mathrm{m})$ Fruit length $(\mathrm{cm})$, Average fruit diameter $(\mathrm{cm})$, Number of fruits per plant, Average fruit weight (g), Fruit yield per plant (kg), Fruit yield (q/ha). The obtained data were subjected to analysis of variance as per the procedure described by Panse and Sukhatme (1961).

\section{Statistical analysis}

Genotypic coefficient of variation (GCV), phenotypic coefficient of variation (PCV), broad sense heritability, genetic advance and genetic gain were computed as per standard formulas

\section{Coefficient of variation $(\%)$}

It is percent ratio of SD of a sample to its means

$\mathrm{CV}=\frac{\mathrm{SD}}{\mathrm{X}} \times 100$

$\mathrm{SD}=$ standard deviation

Parameters for variability estimation as given by Burton and Devane (1953)

i. Phenotypic coefficient of variation (PCV)

$\%=\frac{\sigma_{\mathrm{pi}}-\mu}{\overline{\mathrm{X}}_{\mathrm{i}}} \times 100$

ii. Genotypic coefficient of variation (GCV)

$\%=\frac{\sigma_{\text {gi }}}{\overline{\mathrm{X}}_{\mathrm{i}}} \times 100$

iii. Environmental coefficient of variation

(ECV) $\%=\frac{\sigma_{\mathrm{ei}}}{\overline{\mathrm{X}}_{\mathrm{i}}} \times 100$

Where,

$\sigma_{\mathrm{pi}}=$ Phenotypic standard deviation of $\mathrm{i}^{\text {th }}$ character

$\sigma_{\mathrm{gi}}=$ Genotypic standard deviation of $\mathrm{i}^{\text {th }}$ character

$\sigma_{\text {ei }}=$ Environmental standard deviation of $i^{\text {th }}$ character

$\overline{\mathrm{X}}_{\mathrm{i}}=$ Means of $\mathrm{i}^{\text {th }}$ character

Here,

$$
\sigma_{\mathrm{e}}^{2}(\text { Error variance }) \quad=\mathrm{EMS}
$$




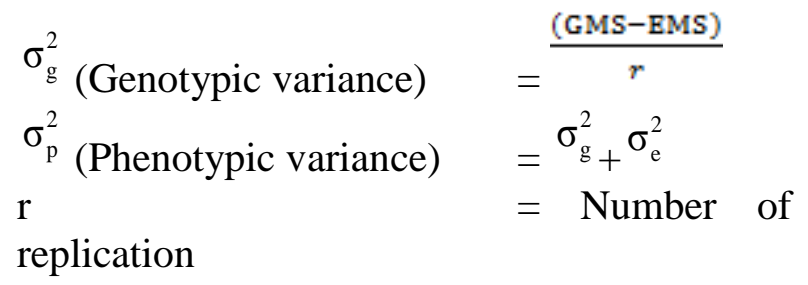

\section{Heritability}

Heritability in board- sense was calculated as per formula given by Burton and Devane (1953) and Allard (1960).

Heritability $\left(\mathrm{h}_{\mathrm{b}}^{2}\right) \%=$

$$
\frac{\text { Genotypic variance }\left(\sigma_{\mathrm{g}}^{2}\right)}{\operatorname{Phenotypic} \operatorname{variance}\left(\sigma_{\mathrm{p}}^{2}\right)} \times 100
$$

\section{Genetic advance}

$\mathrm{GA}=\mathrm{h}^{2}(\mathrm{~b}) \times \sigma_{\mathrm{p}} \times \mathrm{K}$

Where,

$\mathrm{K}=$ Selection intensity, the value of which is 2.06 at $5 \%$ intensity selection.

Genetic advance was expressed as percent of population mean

$\mathrm{GA}(\%$ of mean $)=\frac{\mathrm{GA}}{\overline{\mathrm{X}}} \times 100$

Where,

$\overline{\mathrm{X}}=$ Mean of the character

\section{Results and Discussion}

In the present investigation, the analysis of variance (Table $1 \& 2$ ) revealed significant differences at $1 \%$ level of significance for almost all the characters in both the environments under polyhouse condition which showed a wide range of variability among the 47 genotypes (14 parents and 33 $\mathrm{F}_{1} \mathrm{~s}$ ) for all 15 characters. This would help in selecting the best genotypes from existing collection. Reshmi (2006), Arunkumar et al., (2011) and Veena et al., (2012) also reported similar results in cucumber. From the present experiment (Table $3 \& 4$ ), PCV value was slightly higher than GCV value for all traits which indicated that the characters were not influenced much by environmental effects. High values of phenotypic coefficient of variation as well as genotypic coefficient of variation (> 30\%) were recorded for node number to first male flower, node number to first female flower, sex ratio: $(\mathrm{M} / \mathrm{F})$, days to first male flower, fruit yield/ plant $(\mathrm{kg})$, and fruit yield ( $\mathrm{q} / \mathrm{ha})$ in both the environments. As these traits were showing high GCV and PCV values in both environments, these characters revealed the greater extent of variability present in the genotypes, and less difference between GCV \& PCV values, thereby suggesting good scope for improvement through selection of this crop. Thus, the selection based on phenotypic performance would be reliable. Earlier Punetha, S. (2014) and Tiwari R. (2015), also reported direct selection of germplasms depending upon phenotypic performance in gynoecious and monoecious cucumbers. Likewise, moderate GCV and PCV values (15-30\%) were recorded for no. of fruits per plant, plant height $(\mathrm{m})$, days to first female flower, fruit weight $(\mathrm{g})$, fruit length $(\mathrm{cm})$ in both environments which could be used as potential parameters for further improvement. So, it can be concluded that the coefficients of genotypic and phenotypic variability were observed moderate to high for different characters present under study in cucumber.This was similar with the findings reported by Shah et al., 2018, Kumar et al., 2013 and Krishna Reddy, 2014 in cucumber.In other cucurbitaceous crops, similar findings have also been reported by Singh and Kumar (2002) in bottle gourd, Kutty and Dharmatti (2004) in bitter gourd, Jat et al., (2014) in kakri. 
Table.1 Analysis of variance of different traits in cucumber in E1

\begin{tabular}{|c|c|c|c|c|c|c|c|c|c|c|c|c|c|c|c|c|}
\hline \multirow{2}{*}{$\begin{array}{l}\text { Source of } \\
\text { variation }\end{array}$} & \multirow{2}{*}{$\begin{array}{l}\text { Degree } \\
\text { of } \\
\text { freedom }\end{array}$} & \multicolumn{15}{|c|}{ Mean Squares } \\
\hline & & $\begin{array}{c}\text { Days to } \\
\text { first } \\
\text { male } \\
\text { flower }\end{array}$ & \begin{tabular}{|c|} 
Node \\
number \\
to first \\
male \\
flower
\end{tabular} & $\begin{array}{l}\text { Days to } \\
\text { first } \\
\text { female } \\
\text { flower }\end{array}$ & \begin{tabular}{|c} 
Node \\
number \\
to first \\
female \\
flower
\end{tabular} & $\begin{array}{c}\text { Sex } \\
\text { ratio: } \\
(\mathrm{M} / \mathrm{F})\end{array}$ & $\begin{array}{c}\text { Days to } \\
\text { first } \\
\text { harvest }\end{array}$ & $\begin{array}{c}\text { Days to } \\
\text { last } \\
\text { harvest }\end{array}$ & $\begin{array}{c}\text { Internodal } \\
\text { length } \\
(\mathrm{cm})\end{array}$ & $\begin{array}{l}\text { Plant } \\
\text { height } \\
(\mathrm{m})\end{array}$ & $\begin{array}{c}\text { Fruit } \\
\text { length } \\
(\mathrm{cm})\end{array}$ & $\begin{array}{c}\text { Fruit } \\
\text { diameter } \\
\text { (cm) }\end{array}$ & $\begin{array}{c}\text { Number } \\
\text { of } \\
\text { fruits/ } \\
\text { plant }\end{array}$ & $\begin{array}{l}\text { Average } \\
\text { fruit } \\
\text { weight (g) }\end{array}$ & $\begin{array}{l}\text { Fruit } \\
\text { yield/ } \\
\text { plant } \\
\text { (kg) }\end{array}$ & $\begin{array}{l}\text { Fruit yield } \\
\text { (q/ha) }\end{array}$ \\
\hline Replicate & 2 & 0.13 & 0.00 & 0.84 & 0.28 & 0.00 & 0.66 & 2.39 & 0.00 & 0.07 & 0.02 & 0.00 & 0.03 & 4.72 & 0.00 & 0.38 \\
\hline Treatments & 46 & $996.36 * *$ & $21.50 * *$ & $223.78 * *$ & $76.62 * *$ & $302.63 * *$ & $179.27 * *$ & $222.11 * *$ & $2.82 * *$ & $2.60 * *$ & $17.59 * *$ & $0.70 * *$ & $15.40 * *$ & $2601.38 * *$ & $1.06 * *$ & $70749.22 * *$ \\
\hline Error & 92 & 0.16 & 0.02 & 0.42 & 0.25 & 0.04 & 0.72 & 14.40 & 0.03 & 0.09 & 0.02 & 0.01 & 0.64 & 86.29 & 0.03 & 379.40 \\
\hline
\end{tabular}

$*$ Significant at $5 \%$ probability level $* *$ Significant at $1 \%$ probability level

Table.2 Analysis of variance of different traits in cucumber in E2

\begin{tabular}{|c|c|c|c|c|c|c|c|c|c|c|c|c|c|c|c|c|}
\hline \multirow{2}{*}{$\begin{array}{l}\text { Source of } \\
\text { variation }\end{array}$} & \multirow{2}{*}{$\begin{array}{c}\text { Degree } \\
\text { of } \\
\text { freedom }\end{array}$} & \multicolumn{15}{|c|}{ Mean Squares } \\
\hline & & \begin{tabular}{|c|} 
Days to \\
first \\
male \\
flower
\end{tabular} & $\begin{array}{c}\text { Node } \\
\text { number } \\
\text { to first } \\
\text { male } \\
\text { flower }\end{array}$ & $\begin{array}{c}\text { Days to } \\
\text { first } \\
\text { female } \\
\text { flower }\end{array}$ & $\begin{array}{c}\text { Node } \\
\text { number } \\
\text { to first } \\
\text { female } \\
\text { flower }\end{array}$ & $\begin{array}{c}\text { Sex } \\
\text { ratio: } \\
(\mathbf{M} / \mathbf{F})\end{array}$ & $\begin{array}{c}\text { Days to } \\
\text { first } \\
\text { harvest }\end{array}$ & $\begin{array}{c}\text { Days to } \\
\text { last } \\
\text { harvest }\end{array}$ & $\begin{array}{l}\text { Internodal } \\
\text { length } \\
\text { (cm) }\end{array}$ & $\begin{array}{c}\text { Plant } \\
\text { height } \\
(\mathbf{m})\end{array}$ & $\begin{array}{c}\text { Fruit } \\
\text { length } \\
(\mathrm{cm})\end{array}$ & $\begin{array}{c}\text { Fruit } \\
\text { diameter } \\
(\mathrm{cm})\end{array}$ & $\begin{array}{c}\text { Number } \\
\text { of } \\
\text { fruits/ } \\
\text { plant }\end{array}$ & $\begin{array}{c}\text { Average } \\
\text { fruit } \\
\text { weight (g) }\end{array}$ & $\begin{array}{c}\text { Fruit } \\
\text { yield/ } \\
\text { plant } \\
(\mathbf{k g})\end{array}$ & $\begin{array}{c}\text { Fruit yield } \\
\text { (q/ha) }\end{array}$ \\
\hline Replicate & 2 & 0.21 & 0.00 & 0.30 & 0.13 & 0.00 & 0.06 & 3.77 & 0.03 & 0.34 & 0.01 & 0.00 & 0.02 & 110.19 & 0.09 & 91.39 \\
\hline Treatments & 46 & $791.12 * *$ & $26.93 * *$ & $109.81 * *$ & $105.27 * *$ & $242.66 * *$ & $144.66 * *$ & $198.25 * *$ & $2.36 * *$ & $3.69 * *$ & $19.53 * *$ & $0.64 * *$ & $45.10 * *$ & $3260.08 * *$ & $3.45 * *$ & $238031.63 * *$ \\
\hline Error & 92 & 0.14 & 0.01 & 0.30 & 0.21 & 0.01 & 0.81 & 20.49 & 0.07 & 0.15 & 0.01 & 0.00 & 0.87 & 128.15 & 0.04 & 460.95 \\
\hline
\end{tabular}

$*$ Significant at $5 \%$ probability level $\quad * *$ Significant at $1 \%$ probability level 
Table.3 Estimate of variability parameters for different traits in cucumber in E1

\begin{tabular}{|c|c|c|c|c|c|c|c|c|c|c|c|c|c|c|c|}
\hline \multicolumn{16}{|c|}{ Genetic Parameters (Summary) } \\
\hline & $\begin{array}{l}\text { Days to first } \\
\text { male flower }\end{array}$ & $\begin{array}{c}\text { Node } \\
\text { number } \\
\text { to first } \\
\text { male } \\
\text { flower }\end{array}$ & $\begin{array}{c}\text { Days to } \\
\text { first } \\
\text { female } \\
\text { flower }\end{array}$ & $\begin{array}{c}\text { Node } \\
\text { number } \\
\text { to first } \\
\text { female } \\
\text { flower }\end{array}$ & $\begin{array}{c}\text { Sex } \\
\text { ratio: } \\
(\mathbf{M} / \mathbf{F})\end{array}$ & $\begin{array}{c}\text { Days to } \\
\text { first } \\
\text { harvest }\end{array}$ & $\begin{array}{c}\text { Days to } \\
\text { last } \\
\text { harvest }\end{array}$ & $\begin{array}{c}\text { Internodal } \\
\text { length } \\
\text { (cm) }\end{array}$ & $\begin{array}{c}\text { Plant } \\
\text { height } \\
\text { (m) }\end{array}$ & $\begin{array}{c}\text { Fruit } \\
\text { length } \\
(\mathbf{c m})\end{array}$ & $\begin{array}{c}\text { Fruit } \\
\text { diameter } \\
\text { (cm) }\end{array}$ & $\begin{array}{c}\text { Number } \\
\text { of fruits/ } \\
\text { plant }\end{array}$ & $\begin{array}{l}\text { Average } \\
\text { fruit } \\
\text { weight } \\
\text { (g) }\end{array}$ & $\begin{array}{c}\text { Fruit } \\
\text { yield/ } \\
\text { plant } \\
(\mathrm{kg})\end{array}$ & $\begin{array}{c}\text { Fruit } \\
\text { yield } \\
\text { (q/ha) }\end{array}$ \\
\hline GCV & 57.15 & 91.05 & 18.48 & 64.43 & 129.13 & 12.47 & 7.96 & 12.29 & 25.34 & 15.34 & 11.82 & 30.90 & 17.17 & 35.72 & 35.42 \\
\hline PCV & 57.16 & 91.18 & 18.54 & 64.75 & 129.16 & 12.54 & 8.75 & 12.48 & 26.64 & 15.37 & 12.16 & 32.85 & 18.03 & 37.08 & 35.71 \\
\hline$h^{2}($ Broad Sense) $(\%)$ & 100 & 100 & 99 & 99 & 100 & 99 & 83 & 97 & 90 & 100 & 95 & 88 & 91 & 93 & 98 \\
\hline Genetic advance (GA) & 37.52 & 5.50 & 17.72 & 10.34 & 20.68 & 15.79 & 15.59 & 1.95 & 1.79 & 4.97 & 0.96 & 4.29 & 56.79 & 1.16 & 312.97 \\
\hline $\begin{array}{l}\text { Genetic advance as \% of } \\
\text { mean }\end{array}$ & 89.70 & 92.30 & 37.97 & 89.07 & 93.94 & 25.53 & 14.92 & 24.95 & 49.63 & 31.55 & 23.68 & 59.88 & 33.67 & 70.87 & 72.38 \\
\hline
\end{tabular}

Table.4 Estimate of variability parameters for different traits in cucumber in E2

\begin{tabular}{|c|c|c|c|c|c|c|c|c|c|c|c|c|c|c|c|}
\hline \multicolumn{16}{|c|}{ Genetic Parameters (Summary) } \\
\hline & $\begin{array}{l}\text { Days to } \\
\text { first male } \\
\text { flower }\end{array}$ & $\begin{array}{c}\text { Node } \\
\text { number to } \\
\text { first male } \\
\text { flower }\end{array}$ & $\begin{array}{c}\text { Days to } \\
\text { first } \\
\text { female } \\
\text { flower }\end{array}$ & $\begin{array}{l}\text { Node } \\
\text { Number } \\
\text { to first } \\
\text { female } \\
\text { flower }\end{array}$ & $\begin{array}{c}\text { Sex } \\
\text { ratio: } \\
(\mathbf{M} / \mathbf{F})\end{array}$ & $\begin{array}{c}\text { Days to } \\
\text { first } \\
\text { harvest }\end{array}$ & $\begin{array}{c}\text { Days to } \\
\text { last } \\
\text { harvest }\end{array}$ & $\begin{array}{l}\text { Internodal } \\
\text { length }(\mathrm{cm})\end{array}$ & $\begin{array}{c}\text { Plant } \\
\text { height } \\
(\mathbf{m})\end{array}$ & $\begin{array}{c}\text { Fruit } \\
\text { length } \\
(\mathrm{cm})\end{array}$ & $\begin{array}{c}\text { Fruit } \\
\text { diameter } \\
(\mathbf{c m})\end{array}$ & $\begin{array}{c}\text { Number } \\
\text { of fruits/ } \\
\text { plant }\end{array}$ & $\begin{array}{l}\text { Average } \\
\text { fruit } \\
\text { weight } \\
\text { (g) }\end{array}$ & $\begin{array}{c}\text { Fruit } \\
\text { yield/ } \\
\text { plant } \\
(\mathbf{k g})\end{array}$ & $\begin{array}{l}\text { Fruit } \\
\text { yield } \\
\text { (q/ha) }\end{array}$ \\
\hline GCV & 56.73 & 74.99 & 14.54 & 68.36 & 146.31 & 11.13 & 7.22 & 7.91 & 22.44 & 15.89 & 11.43 & 37.52 & 18.28 & 44.05 & 44.05 \\
\hline PCV & 56.75 & 75.04 & 14.60 & 68.57 & 146.32 & 11.22 & 8.38 & 8.25 & 23.82 & 15.90 & 11.48 & 38.61 & 19.37 & 44.88 & 44.18 \\
\hline $\begin{array}{l}h^{2}(\text { Broad Sense }) \\
(\%)\end{array}$ & 100 & 100 & 99 & 99 & 100 & 98 & 74 & 92 & 89 & 100 & 99 & 94 & 89 & 96 & 99 \\
\hline Genetic advance (GA) & 33.44 & 6.17 & 12.40 & 12.15 & 18.53 & 14.15 & 13.67 & 1.73 & 2.11 & 5.25 & 0.95 & 7.69 & 62.82 & 2.15 & $\begin{array}{c}578 . \\
02\end{array}$ \\
\hline $\begin{array}{l}\text { Genetic advance as \% of } \\
\text { mean }\end{array}$ & 88.84 & 91.37 & 29.83 & 90.40 & $\begin{array}{l}94 \\
.40\end{array}$ & 22.74 & 12.82 & 15.60 & 43.54 & 32.71 & 23.43 & 75.12 & 35.55 & 89.05 & 90.48 \\
\hline
\end{tabular}


The heritability estimate gives an idea about the proportion of observed variability, which is attributed to genetic difference. Heritability in broad sense may play greater role about information of relative value of selection, but Johnson et al., (1955) had shown that heritability and genetic advance should be jointly considered for reliable conclusion. In the present study, all the traits expressed high heritability which ranged from 74-83\% (days to last harvest) to $100 \%$ (fruit length, days \& node to first male flower) in both the environments (Table $3 \& 4$ ). The results in the experiment revealed higher heritability estimate for all the characters. High heritability indicates less influence of environment and is governed by additive gene effects. Similar results were also reported by Dhiman and Chander Prakash (2005) and Arunkumar et al., (2011) and Veena et al., (2012). The above results are also corroborated with the findings of Sanwal et al., (2007) in sweet gourd, Singh et al., (2008) in ridge gourd, Kumar et al., (2008), Hanchinamani et al., (2011), Veena et al., (2012), Kumar et al., (2013) and Rajawat and Collis (2017) in cucumber,

Genetic advance under selection depends mainly on the extent of genetic variability in the base population, intensity of the selection, magnitude of the masking effect of environment and interaction components of variability High heritability along with high genetic advance indicate that the heritability is mostly due to additive gene effects and selection may be effective. In the present study out of 15 characters studied, high genetic advance (> 30\%) over mean coupled with high heritability was observed in characters like fruit length, fruit weight, number of fruits/plant, plant height, yield per plant, yield per hectare, days to first male flower, node to first male flower, node to first female flower and sex ratio. These findings are more stable across the environments under polyhouse and the genotypes associated with traits mainly due to additive type of genes Therefore, they are more reliable for effective selection. Similar findings were reported by different workers that high estimate of heritability along with high genetic advance for all the traits under study revealed the characters were controlled by additive gene action (Kumar et al., 2008; Veena et al., 2012 and Yadav et al., 2009)

The internodal length,fruit diameter, days to first female flower, days to first harvest were high heritability along with moderate genetic advance (15-30\%) which revealed the additive gene action coupled with nonadditive gene action. In this case, the selection could be ineffective. The traits can be improved by mass selection, (Shah et al., 2018). Higher heritability estimates were accompanied by lower genetic advance (< $15 \%$ ) over the mean for days to last harvest. This suggests that selection may not be useful for the improvement of this trait because of predominance of non-additive gene action which could be exploited through heterosis breeding. Hanchinamani (2006) reported low genetic advance in cucumber.

In conclusion, the overall stable phenotypic performance of Parthenocarpic \& Gynoecious cucumber genotypes in two different environmental conditions under a polyhouse structure is a good indicator of optimum selection criteria for improvement in parthenocarpic \& gynoecious cucumber breeding in India. It is fact that traits having high heritability coupled with high level of genetic advance are due to greater contribution of additive genetic components and therefore, these traits could be improved by direct selection in segregating generations. Now, it is concluded that traits like fruit length, fruit weight, number of fruits/plant, plant height, yield per plant, yield per hectare, days to first male flower, node to first male 
flower, node to first female flower and sex ratio can be considered as suitable selection criteria for the improvement of high yielding cucumber varieties.

\section{References}

Afroz, S., Noman, M.S., Hossain, M.S., Mamun, A.A., Howlader, N. and Ara, S. 2015. Multivariate analysis approach to select parents for hybridization aiming at yield improvement in cucumber (Cucumis sativus L.). J. Environ. Sci. Natural Resour. 6: 33-36.

Allard, R.W. 1960. Principles of Plant Breeding. New York, John Wiley and Sons.

Arunkumar, K.H., Patil, M.G., Hanchinamani, C.N., Goud, I.S. and Hiremath, S.V. 2011. Genetic relationship of growth and development traits with fruit yield in $\mathrm{F} 2$ population of BGDL $\mathrm{x}$ Hot season of cucumber (Cucumis sativus L.). Kar. J. Agri. Sci., 24(4): 497-500.

Burton, G.W. and De Vane, E.M. 1953. Estimation of heritability in tall fescue (Festica arundinaceae) from replicated clonal material. Agron. J 45: 478-481.

Deakin, J.R., G.W. Bohn, and T.W. Whitaker. 1971. Interspecific hybridization in Cucumis. Econ. Bot. 25:195-211.

Dhiman and Prakash, C. 2005. Correlation and path coefficient analysis in cucumber. Haryana J. Horti. Sci., 34(12): 111-112.

Hanchinamani, C.N. 2006. Genetic Variability, Divergence, Heterosis and Combining Ability Studies in Cucumber (Cucumis sativus L.). Ph.D. Thesis, submitted to Uni. Agri. Sci. Dharwad, India.

Hanchinamani, C.N., Patil, M.G., Dharmatti, P.R. and Mokashi, A.N. 2011. Studies on heritability and genetic advance in cucumber (Cucumis sativus L.). Crop Res., 41(1, 2 \&3): 160-163.
Jat, R. K., Ameta, K.D. and Choudhary, R.C. 2014. Genetic variability, heritability and genetic advance for yield and yield attributing traits in valan kakri (Cucumis sativus var. utilismus L.). The Ecoscan, 6: 317-322.

Johnson, H.W., Robinson, H.F. and Comstock, R.E. 1955. Estimates of genetics and environmental variability in soybean. Agron. J., 47(7): 314-318.

Krishna Reddy, A.N., Munshi, A.D., Behera, T.K., Sureja, A.K. and Sharma, R.K. 2014. Studies on combining ability in cucumber. Indian J. Hort. 71: 349-353.

Kumar, A., Kumar, S. and Pal, A.K. 2008. Genetic variability and characters association for fruit yield and yield traits in cucumber. Indian J. Hort., 65(4): 423-428.

Kumar, S., Kumar, D; Kumar, R; Thakur, K.S. and Dogra, B.S. 2013. Estimation of genetic variability and divergence for fruit yield and quality traits in cucumber (Cucumis sativus L.) in North-Western Himalayas. Uni. J. Plant Sci., 1(2): 2736.

Kutty M.S. and Dharmatti P.R. Genetic variability studies in bitter gourd (Momordica charantia L.). Karnataka Journal of Horticulture, 2004; 1(1):1115.

Panse, V.G and Sukhatme, P.V. 1961. Statistical Methods for Agriculture Workers. II Ed. ICAR, New Delhi.

Pati, K., Munshi, D.A. and Behera, K.T. 2015c. Inheritance of gynoecism in cucumber (Cucumis sativus L.) using genotype GBS-1 as gynoecious parent. Genetika 47: 349-356.

Pike, L.M. and Peterson C.E. 1969.Inheritance of parthenocarpy in the cucumber (Cucumis sativus L.). Euphytica, 18: 101-105.

Pradhan, S.R., Dharmatti, P.R., Sahu, G.S. and Sahoo, T.R. 2016. Combining ability studies for yield and yield 
attributing characters in cucumber (Cucumis sativus L.). Bioscan 11: 30753080.

Punetha, S. 2014. Molecular characterization of parental lines and genetical studies in crosses of cucumber (Cucumis sativus L.) Thesis, PhD. G. B. Pant University of Agriculture and Technology, Pantnagar. $165 \mathrm{p}$.

Rajawat K.S. and Collis J.P. 2017. Genetic variability, Heritability and Genetic advances analysis for quantitative and qualitative traits in Cucumber (Cucumis sativus L.). Journal of Pharmacognosy and Phytochemistry, 6(4): 882-885.

Reshmi N. 2006. Genetic variability, divergence, heterosis and combining ability studies in cucumber (Cucumis sativus). Ph. D. thesis, Univ. Agric. Sci. Bangalore.130 p.

Sanwal, S.K., Yadav, R.K., Rai, N., Yadav, D.S. and Singh, P.K. 2007. Genetic diversity and interrelation analysis in sweet gourd (Momordica cochinchinensis) genotypes of Northeast India. Veg. Sci., 34(1): 64-66.

Shah, K.N., Rana, D.K. and Singh, V. 2018. Evaluation of Genetic Variability, Heritability and Genetic Advance in Cucumber (Cucumis sativus L.) for Various Quantitative, Qualitative and Seed Characters. Int. J. Curr. Microbiol. App. Sci, 7: 3296-3303.

Shukla S, Bhargava A, Chatterjee A, Srivastava A, Singh SP. Genotypic variability in vegetable amaranth (Amaranthus tricolor L.) for foliage yield and its contributing traits over successive cuttings and years. Euphytica, 2006; 151(1):103-110.

Singh DK, Kumar R, Studies on the genetic variability in bottle gourd. Progressive Horticulture, 2002; 34(1):99-101.

Singh, D.K., Maurya, S.K., Jaiswal, H.R. and Singh, A. 2008. Studies on genetic variability and genetic divergence analysis in ridge gourd [Luffa acutangula (Roxb.) L.]. Prog. Hort., 40(2): 149-154.

Staub, J.E., Robbins, M.D., Chung, S. and Sun, Z. 2006. Application of molecular markers for cucumber improvement. In: Cucurbitaceae Proceedings held on $25^{\text {th }}$ August 2006 pp. 401-402.

Tiwari, R. 2015. Molecular characterization and genetical studies in cucumber (Cucumis sativus L.) Thesis, $\mathrm{PhD}$. GB Pant University of Agriculture and Technology, Pantnagar. 129 p.

Veena, R., Sidhu, A.S., Pitchaimuthu, M. and Souravi. K. 2012. Genetic evaluation of cucumber (Cucumis sativus L.) genotypes for some yield and related traits. Elec. J. Plant Breed., 3(3): 945948.

Yadav, Y.C., Kumar, S., Bisen, B. and Dixit, S.K. 2009. Genetic variability, heritability and genetic advance for some traits in cucumber. Indian J. Hort. 66: 488-491.

\section{How to cite this article:}

Sahoo, T. R. and Singh, D. K. 2020. Estimation of Genetic Variability, Heritability and Genetic Advance in Cucumber (Cucumis sativus L.) for Yield and Its Components under Protected Structure. Int.J.Curr.Microbiol.App.Sci. 9(04): 2756-2764. doi: https://doi.org/10.20546/ijcmas.2020.904.325 